\title{
SOCIOLOGIA DO TRABALHO NO BRASIL Entrevista com Leôncio Martins Rodrigues
}

\section{Por José Ricardo Ramalho e Iram Jácome Rodrigues}

Esta entrevista oferece uma oportunidade ímpar de se conhecer, através das palavras de um dos seus pioneiros, parte significativa da história da sociologia do trabalho no Brasil. O relato de Leôncio Martins Rodrigues revela aspectos de uma trajetória de vida voltada para a pesquisa, para a orientação acadêmica de novas gerações e para a reflexão sobre o ofício de cientista social.

A formação em Ciências Sociais, que se inicia no final dos anos de 1950, traz a marca da USP sob a influência de Florestan Fernandes e seus assistentes. O modo como diferentes gerações de intelectuais passaram a estudar e pesquisar sistematicamente o Brasil tem um enorme valor para se entender o processo de consolidação da nossa sociologia como disciplina. $\mathrm{O}$ mesmo se aplica à descriçãao de como as diversas influências teórico-

Entrevista recebida em setembro/2009

Aprovada em novembro/2009 metodológicas foram incorporadas à produção científica. Tal é o caso, por exemplo, da teoria marxista, que "começou a ser cultivada no mundo acadêmico, ao mesmo tempo em que saía do meio operário e sindical”. Para Leôncio, embora já houvesse muitos trabalhos de orientação marxista, a introdução dessa teoria nas universidades se deu principalmente "pelo portão da Faculdade de Filosofia, Ciências e Letras da USP, na rua Maria Antônia". Textos de Marx passaram a ser obrigatórios e sua difusão "ganhou impulso com os seminários de estudo d' $O$ Capital'. Embora não fizesse parte do núcleo central do seminário ("composto por professores de prestígio da USP”), Leôncio, como aluno, presenciou e acompanhou de perto essa iniciativa, com a peculiaridade de já ter ingressado na universidade com uma prática de militância política em um grupo trotskista. "Ao contrário da maioria dos estudantes que se politizam depois de entrar na universidade, eu tinha me politizado antes, ainda no colegial". 
A lealdade com Florestan aparece no episódio que resultou na ordem de prisão ao professor emitida pelo coronel encarregado do IPM da USP. Leôncio colaborou para distribuir entre os estudantes e a imprensa a carta que Florestan tinha lido em seu depoimento. E no retorno da prisão, quando quis passar pela Faculdade na Maria Antônia, participou com ele de um dos eventos mais espontâneos de resistência à arbitrariedade militar: "Ao entrarmos pela porta principal, o bedel e outras pessoas que estavam no saguão de entrada [...] começaram a bater palmas. [...] Os alunos saíram das salas de aula para ver o que se passava viram Florestan e começaram também a aplaudir [...]".

Leôncio faz também uma reflexão sobre sua experiência de militância política, considerada por ele hoje "valiosa para a atividade de sociólogo e cientista político". Se inicialmente lamentou o tempo de sua juventude "desperdiçado [...] na atividade revolucionária", agora reconhece "que não foram [anos] perdidos": "Partidos de esquerda são uma espécie de escola onde se aprende determinadas matérias, onde se adquire uma experiência de vida e se forma uma rede de relacionamento que pode ser útil profissionalmente".

Em sua atuação como pesquisador e professor da USP, Leôncio descreve e sistematiza todo um conjunto de atividades que constituíram os primórdios da sociologia do trabalho no Brasil. Refere-se também à sua interlocução com outros autores dessa área de estudos, como Juarez Brandão Lopes, Azis Simão e José Albertino Rodrigues. Fala da criação do Centro de Sociologia Industrial e do Trabalho (Cesit) nos anos de 1960, do programa de pesquisas sobre a estrutura da empresa industrial em São Paulo e de sua contratação como pesquisador desse centro. "Usei os dados da pesquisa [...] para fazer meu mestrado sobre a ocorrência de greves no setor industrial". No doutorado, escolheu fazer um estudo de caso sobre a montadora de automóveis Willys Overland. "Estávamos dando os primeiros passos na área da sociologia industrial ou da sociologia do trabalho". O foco deste estudo foram os "trabalhadores manuais, os 'horistas', a maioria deles localizados na linha de montagem". A tese de doutorado foi publicada posteriormente com o título Industrialização e atitudes operárias.

Leôncio Martins Rodrigues nasceu na cidade de São Paulo, em 1934. Professor titular da Universida- de de São Paulo e da Universidade de Campinas fez sua carreira acadêmica (graduação, mestrado, doutorado, Livre-docência e Titulação) na USP, tendo publicado dezesseis livros, alguns dos quais se tornaram obras de referência e leitura obrigatória para os pesquisadores do mundo fabril e da classe trabalhadora industrial. Podemos citar, como exemplo, Conflito industrial e sindicalismo no Brasil; Industrialização e atitudes operárias; Trabalhadores, sindicatos e industrialização; CUT: os militantes e a ideologia; Destino do sindicalismo; e mais recentemente Partidos, ideologia e composição social; e Mudanças na classe politica brasileira. No exterior, foi professor visitante na Universidade de Louvain, na Bélgica, e diretor de estudos na Escola de Altos Estudos em Ciências Sociais, em Paris; no Brasil foi sócio-fundador do Cebrap, do conselho deliberativo do Cedec, participou do Idesp e do CNPq e atualmente participa do Instituto Fernando Henrique Cardoso, do Instituto Fernando Braudel de Economia Mundial, da Academia Brasileira de Ciências, entre outros.

A seguir apresentamos a entrevista que concedeu durante sessão do curso "Sociologia do Trabalho no Brasil” (PPGSA-IFCS-UFRJ), em 10 de setembro de 2007, no prédio do Instituto de Filosofia e Ciências Sociais da UFRJ. ${ }^{1}$ A transcrição final foi revista e editada pelo autor.

Quando José Ricardo me convidou, por um momento, fiquei na dúvida se deveria ou não aceitar dar a entrevista. Mas quando ele disse "queremos escutálo sobre a sua carreira", concordei imediatamente. Como acontece com a maioria das pessoas, especialmente com os intelectuais, não me desagrada falar sobre mim mesmo... Mas, além disso, esperava passar alguma informação sobre os inícios da sociologia do trabalho em São Paulo e, quem sabe, transmitir alguma experiência de pesquisa para as novas geraçōes.

\section{Origens sociais: a militância trotskista}

Começo falando sumariamente de minhas origens e como fui cair no curso de Ciências Sociais da USP. Nasci em São Paulo, em 1934. Meu pai era 
funcionário público. Trabalhava na Secretaria da Agricultura num serviço de proteção da fauna. Moramos em várias cidades do interior. Quando estava com 16 anos, voltamos para a Capital, depois de morar por cinco anos em Santos. A mudança para São Paulo foi muito importante para minha vida. Por influência de um tio que era do Partido Socialista Brasileiro (PSB) passei a freqüentar a sede do diretório municipal do partido. Estávamos em 1950. Em outubro, haveria eleições. O PSB tinha João Mangabeira como candidato à presidência. Getúlio Vargas era favorito, concorrendo pelo PTB e o PSD. O Brigadeiro Eduardo Gomes, candidato da UDN, era seu principal adversário.

Nessa ocasião, havia dentro do PSB um grupo trotskista infiltrado. $\mathrm{Na}$ época, os trotskistas se autodenominavam Partido Socialista Revolucionário (PSR). (Alguns anos depois, o nome mudou para Partido Operário Revolucionário, POR.) Comecei a ler o material que me passavam. O PSR era muito pequeno. Vivia numa clandestinidade rigorosa e desnecessária, como se o FBI, a GPU e o DOPS estivessem muito preocupados com nossas atividades. Tínhamos ligação com um ou outro sindicato de trabalhadores. Contudo, a composição do partido era majoritariamente pequeno-burguesa. Por isso, decidiu-se que eu deveria trabalhar numa fábrica (me "proletarizar"), o que fiz por mais ou menos dois meses. Por sorte, fui escolhido como um dos delegados brasileiros ao IV Congresso da IV Internacional a realizar-se na França em 1954. Tinha 20 anos. Foram enviados dois delegados. O outro era um argentino, apenas quatro anos mais velho do que eu. Pertencia ao grupo do Posadas, a tendência trotskista dominante na Argentina. Ele tinha sido enviado ao Brasil como assessor da secção brasileira, na verdade para nos "educar" na linha posadista.

Eu tinha entrado para o PSR com cerca de 17 anos. Com o tempo, cheguei a ser secretário de organização, posto mais importante depois do secretário político. Mais tarde, penso que em 1955, passei a integrar o Bureau Latino-Americano. No segundo semestre de 1956, abandonei a militância. Havia me convencido de que o trotskismo não teria futuro e que não era muito diferente do stalinismo. Alem disso, queria voltar a estudar. Tinha "descoberto” as ciências sociais graças à Ruth Cardoso. Ela tinha sido minha professora de história no curso colegial do Colégio Fernão Dias Paes. Fernando Henrique também deu algumas aulas nesse colégio, mas não foi meu professor. Por coincidência, eu a reencontrei como técnica num serviço de pesquisas sobre mão-de-obra da Secretaria do Trabalho, onde eu era funcionário subalterno. Ela me falou sobre o curso de ciências sociais. Era exatamente o que queria estudar. Como tinha abandonado os estudos, tive que fazer mais dois anos de colegial para poder prestar vestibular. Preferi cursar, no período noturno, dois anos de curso Normal que também dava acesso ao vestibular de ciências sociais. Desse modo, acabei ficando cerca de seis anos atrasado com relação à idade de entrada habitual na universidade. Obtive o diploma aos 29 anos.

\section{A rua Maria Antônia: curso de ciências sociais}

Em 1958, quando me matriculei, o curso de ciências sociais tinha poucos alunos e poucos professores. Na Cadeira de Sociologia I, o professor Florestan Fernandes era o regente. Havia apenas cinco professores: além do Florestan, o chefe, como às vezes entre nós o chamávamos, estavam Fernando Henrique (que era o primeiro assistente), Octávio Ianni, Maria Sylvia de Carvalho Franco e Maria Alice Mencarini Foracchi, que faleceu muito cedo.

A orientação predominante era funcionalista e estruturalista, como aliás em todo mundo. Os primeiros trabalhos de Florestan, sobre a organização social dos Tupinambá, eram estritamente funcionalistas, como indicava o título de um de seus primeiros livros: A função social da guerra entre os Tupinambá. Talcott Parsons, Merton, Durkheim, Mannheim, Tonnies e Weber eram os grandes nomes do curso de primeiro ano, ministrado por Fernando Henrique. Uma boa indicação da orientação teórica e metodológica predominante na época encontra-se num livro que passou por várias edições. Trata-se de uma antologia de textos de sociologia intitulada Homem e sociedade, organizada por Fernando Henrique e Octávio Ianni.

Essa antologia iniciava-se com um capítulo sobre o conceito de sociologia. Redigido pelo Flores- 
tan, era o único cujo autor era brasileiro. Os outros dezoito capítulos eram de autores norte-americanos e europeus. Só de Talcott Parsons, mais tarde execrado como funcionalista, havia quatro. Os textos estavam voltados para questôes conceituais na área de sistemas, processos e interação social. Só no capítulo final aparecia um texto de Marx denominado "A ideologia em geral".

\section{O marxismo acadêmico}

Não havia nada de assombroso nessa seleção. Marx não penetrava na academia, aqui e em outros países. Foi por volta da década de 1960 que a teoria marxista começou a ser cultivada no mundo acadêmico, ao mesmo tempo em que saía do meio operário e sindical, fenômeno interessante, mas que não seria possível discutir aqui. Fiquemos com algumas palavras sobre a transformação, aqui no Brasil, do marxismo em ciência sociológica.

Certamente, fora da academia, já havia muitos trabalhos de interpretação do Brasil de orientação marxista, como os de Caio Prado Jr. e de Leôncio Basbaum. A entrada, porém, do marxismo nos meios acadêmicos se deu principalmente pelo portão da Faculdade de Filosofia, Ciências e Letras da USP, na rua Maria Antônia. Daí se estendeu para outras universidades e instituições acadêmicas do país. Essa trajetória acompanhava o que acontecia no Primeiro Mundo. A França era o principal foco de irradiação, com Poulantzas e Althusser à frente. Textos de Marx eram obrigatórios num curso de sociologia que se pretendesse de alto nível e não quisesse ser classificado como de "direita".

Em São Paulo, a difusão do marxismo acadêmico ganhou impulso com os seminários de estudo d'O Capital. O seminário estava composto por professores de prestígio da USP. Alguns tinham militância política, outros não. Houve variação na participação. O núcleo central e mais constante era formado pelos seguintes professores: Fernando Henrique Cardoso, José Arthur Giannotti, Octavio Ianni, Paul Singer, Roberto Schwartz, Fernando Novais, Juarez Brandão Lopes, Francisco Weffort, Michel Löwy e Ruth Cardoso, a única mulher participante. Livros considerados importantes, como
Histoire et conscience de classe, de Georg Lukács, então na moda, poderiam também ser discutidos e interromper por um momento a leitura e a discussão de um capítulo d'O Capital. Uma vez me pediram que fizesse uma exposição sobre o que era a teoria da revolução permanente de Trotsky.

O professor Florestan não participava. Não sei se chegou a ser convidado ou foi e recusou. No seu livro $A$ sociologia no Brasil, no capítulo em que traça uma ligeira biografia de sua vida, escreveu que tinha sido excluído, mas tinha achado natural porque era "o professor". Nessa ocasião, eu era aluno do curso de ciências sociais. Fui convidado para o seminário por especial deferência e participei da discussão de alguns capítulos. Mas quando cheguei, o grupo já tinha lido vários capítulos. Uma vez que não tinha participado dos seminários iniciais, achei que podia ficar uma lacuna no meu conhecimento. Por isso, decidi não continuar. Com a Eunice Durham, ajudei a criar outro grupo de estudos da nova Bíblia, começando do começo. Mas esse seminário d'O Capital - um dos muitos que se formaram na época - não durou muito. Não me lembro a razão de seu término.

No meu caso, ao contrário da maioria dos estudantes que se politizam depois de entrar na universidade, eu tinha me politizado antes, ainda no colegial. Vinha de cerca de seis anos de militância intensa e dedicação total ao "partido". Assim, já tinha lido boa parte da literatura marxista e leninista mais difundida (além dos livros de Trotsky, é claro). Passara a ver o marxismo com críticas. Especialmente com relação a $O$ Capital, cada vez mais julgava sua leitura uma perda de tempo para compreender o mundo moderno. Por que estudar o capitalismo do século XIX, e não o capitalismo do século XX, ou o socialismo real? Acontece que tinha começado a ler Raymond Aron, Ralf Dahrendorf, Galbraith, James Burham e outros autores "de direita" que pareciam capazes de abrir outras pistas para explicar melhor as sociedades industriais da segunda metade do século XX.

\section{A escola da militância}

Quero fazer uma pequena reflexão sobre minha militância de esquerda, que retardou a obtenção do 
diploma. Durante um bom tempo, lamentei os anos desperdiçados na atividade "revolucionária". Hoje, percebo que não foram totalmente perdidos. Partidos de esquerda são uma espécie de escola onde se aprende determinadas matérias, onde se adquire uma experiência de vida e se forma uma rede de relacionamento que pode ser útil profissionalmente. A atividade política, mesmo em pequenas organizações de esquerda, pode ajudar o êxito profissional e a ascensão social. Naturalmente, não seria preciso dizer, sob ditaduras de direita, pode trazer alguns riscos.

Mas para que a experiência da militância de esquerda possa render frutos na vida profissional e social, é preciso que certas condições para a ascensão social - como a obtenção de um diploma universitário - sejam preenchidas. No meu caso, a entrada tardia na universidade trouxe alguns prejuízos, mas trouxe algumas vantagens na competição com meus colegas mais jovens: permitiu-me trazer para a carreira acadêmica uma experiência profissional anterior que foi importante. Ademais, militância sempre é valiosa para a atividade de sociólogo e de cientista político. Sem recomendar a ninguém qualquer militância de esquerda (e muito menos de direita), creio que a militância partidária de esquerda na juventude traz uma experiência útil de análise dos fatos políticos... e de conchavos.

\section{A entrada na carreira}

Passo agora aos inícios de minhas atividades como pesquisador e professor da USP. Naquela época, não havia concurso para a entrada na docência. A escolha era do regente da cadeira que escolhia seus auxiliares, ou dava a última palavra quando a sugestão inicial era de um de seus assistentes. Foi o que aconteceu comigo e com outros que entraram para a cadeira nesse momento. No início da década de 1960, o sociólogo francês Alain Touraine, nessa altura começando sua carreira, veio para um período de palestras no Departamento de Ciências Sociais. Essas palestras eram dadas em francês e somente para professores. Contudo, foi aberta a uma exceção para mim. Foi mais ou menos nessa ocasião que Fernando Henrique teve a idéia de criar o Cen- tro de Sociologia Industrial e do Trabalho, o Cesit. Fernando tornou-se seu diretor. Como disse, na cadeira de Sociologia I (existia a cadeira de Sociologia II), havia apenas cinco professores. Nesse momento, entrou mais dinheiro e recursos na cadeira e no Cesit. Com isso, foi possível contratar cinco novos pesquisadores para o Cesit. Eu estava entre eles. Vieram nesta ocasião, além de mim, Lourdes Sola, Celso Beisiguel, Gabriel Bolaffi e o José Carlos Pereira.

Um programa de pesquisas alentado foi elaborado. Decidiu-se começar por um survey sobre a estrutura da empresa industrial em São Paulo, com uma amostra de trezentas empresas. Esse survey seria feito pelos cinco pesquisadores recém-contratados com participação da Maria Sylvia Carvalho Franco e de um sociólogo inglês, Bertram Hutchinson, que trabalhava na Unesco. Dos resultados do survey deveria sair nosso mestrado. No programa de pesquisas elaborado na cadeira, Fernando Henrique faria um estudo sobre empresários; Octávio Ianni, sobre o Estado. Florestan Fernandes faria um estudo de interpretação mais geral da sociedade brasileira.

Depois que terminassem o mestrado, os novos pesquisadores do Cesit deveriam fazer para doutorado uma monografia sobre cinco empresas industriais. Para essa pesquisa, cada um dos cinco recémcontratados ganhou dois auxiliares, o que era um luxo para quem estava começando.

A situação política brasileira no início da década de 1960, sob governo Jango e avanço da esquerda nacionalista, estava muito conturbada. Não era fácil se concentrar no trabalho acadêmico. Apesar disso, vários dos projetos planejados pela cadeira de Sociologia I e pelo Cesit chegaram ao fim. Usei os dados da pesquisa sobre estrutura da empresa industrial em São Paulo para fazer meu mestrado sobre a ocorrência de greves no setor industrial, intitulado Greves operárias em S. Paulo. Foi publicado como a segunda parte do meu primeiro livro, Conflito industrial e sindicalismo no Brasil, que saiu em pela Difusão Européia do Livro, em 1966.

Para o doutorado, que deveria ser um estudo de caso, escolhi a Willys Overland. Na ocasiāo, era a maior empresa automobilística brasileira, com cerca dez mil empregados. A intenção inicial era estudar toda a empresa, fato indicativo de minha 
inexperiência. Estávamos dando os primeiros passos na área da sociologia industrial ou da sociologia do trabalho. Não havia quem me orientasse. A diretoria da Willys concordou com o estudo e minha entrada na fábrica de São Bernardo. Mas, ao tomar contacto pela primeira vez com a fábrica, me dei conta de que teria que restringir meu foco de estudo, do contrário nunca chegaria ao fim do doutorado. Como tinha muitas leituras anteriores sobre sindicalismo e trabalhadores, resolvi estudar os trabalhadores manuais, os "horistas", a maioria deles localizados na linha de montagem. Por outro lado, essa escolha tinha uma ponte com minhas preocupações marxistas da época de militância.

Do ponto de vista da qualificação profissional e atividade na produção, esses trabalhadores eram o que os franceses chamam de O. S (ouvriers spécialisés), operários especializados na realização de tarefas repetitivas que não requerem longa formação profissional. Para o Brasil, corresponderiam, grosso modo, aos semiqualificados. No caso, o estudo se concentraria numa parcela da classe operária empregada num dos setores fabris mais avançados da época, setor que deveria representar o futuro e, conseqüentemente, permitiria algum prognóstico sobre o comportamento do proletariado brasileiro. $\mathrm{Na}$ realidade, o trabalho em série na Willys só poderia ser visto como o futuro porque a automação não começara.

Dessa pesquisa resultou minha tese de doutorado, defendida em 1967. Foi publicada em 1970 pela editora Brasiliense com o título Industrialização e atitudes operárias. O termo "atitudes" não era ideologicamente correto. Cheirava sociologia norte-americana e era um pouco "psicologizante". Deveria ter dito consciência operária. Mas o termo que utilizei me parecia mais adequado para o tipo de pesquisa empírica que eu tinha feito.

Para esse trabalho, as influências mais fortes vieram de Touraine e Juarez Brandão Lopes, embora ambos não partilhassem da mesma orientação metodológica. Touraine (junto com a Orietta Ragazzi) havia publicado em 1961 os resultados de uma pesquisa chamada Operários de origem agrícola, em que chamava a atenção, numa fábrica francesa, para certos traços específicos do comportamento de operários vindos da agricultura. Essa pesquisa, e depois outro de seus livros, A consciência operária, ofereceram-me muitos elementos para a análise dos operários da Willys, onde a grande maioria dos semiqualificados tinha vindo do campo. Mas, apesar da influência de Touraine e da sociologia do trabalho francesa, como disse, não usei, no título do meu livro, o termo "consciência".

A pesquisa do Juarez sobre operários metalúrgicos ("O ajustamento do trabalhador à industria: mobilidade social e motivação"), de 1960, também me ajudou bastante. Esse estudo trouxe pistas importantes para a compreensão da conduta do grupo operário. $\mathrm{Na}$ época, era uma das poucas pesquisas que estudava operários fabris. Juarez não vinha do marxismo. Estudou os trabalhadores "tal qual eles eram" e não a classe operária teórica do marxismo. Nessa pesquisa, chamou a atenção para o grande numero de operários vindos da agricultura, as aspirações de ascensão social e a elevada mobilidade profissional dos trabalhadores de baixa qualificação. Teve a chance de presenciar a ocorrência de uma greve, o comportamento dos operários diante do movimento grevista e captar suas opiniōes sobre o sindicato, "visto pelos operários como algo feito por outros para eles". Mais recentemente, Juarez notou com bom humor que essa frase acabou sendo uma das mais citadas em estudos sobre o comportamento operário no Brasil.

De quando é o livro Sindicalismo e sociedade?

De 1968. É uma antologia. A idéia era difundir alguns artigos com análises mais sociológicas e menos ideológicas sobre o sindicalismo e a classe operária. Havia um texto de Touraine com Bernard Mottez e outro de Michel Crozier. Incluía também um artigo polêmico de Lipset sobre os trabalhadores norte-americanos e os valores da sociedade norte-americana.

Nessa época, além da pesquisa do Juarez Brandão Lopes, Azis Simão (que era da cadeira de Sociologia II) já havia publicado alguns trabalhos como "O voto operário em São Paulo". Nesse estudo, mostrou a relação do voto operário com o PCB e, depois da cassação da legenda comunista, com o PTB. Azis Simão havia também publicado o livro Sindicato e Estado. Fernando Henrique tinha escri- 
to um artigo sobre uma greve de sapateiros em São Paulo de antes da Primeira Guerra Mundial. Lembro-me também de uma pequena pesquisa feita por Michel Löwy e Sara Chucid sobre atitudes e opinióes de lideres sindicais metalúrgicos de 1964. Mas era pouca coisa em comparação ao que existe hoje.

\section{E Evaristo?}

O livro O problema do sindicato único no Brasil é uma obra importante para o estudo do nosso modelo corporativo. Mas Evaristo vinha de uma tradição jurídica. O livro era sobre a estrutura sindical e tinha uma abordagem jurídica. Não era um livro de pesquisa sociológica. Por isso não o mencionei.

\section{Como surgiu a idéia do livro sobre a CUT?}

A iniciativa veio da CUT. A proposta foi que eu dirigisse uma pesquisa com delegados ao III Congresso da CUT, o Concut, que seria realizado em Belo Horizonte, em setembro de 1988. A pesquisa teria o apoio do Instituto Latino-Americano de Desenvolvimento Econômico e Social (Ildes). Houve um acordo entre mim e a CUT. Não receberia nada como pagamento, mas teria os dados para redigir um trabalho. A CUT teria uma cópia das tabelas e daria um apoio administrativo: pessoal para aplicação dos questionários, tabulação etc. Por isso, houve duas publicações: o meu livro e um caderno impresso pela própria CUT.

Mas teve toda uma repercussão com a CUT, que reagiu...

Eu planejei e dirigi toda a pesquisa. Mas contei com a colaboração de uma assessora da CUT, Maria Sílvia Portela de Castro (que mais tarde fez mestrado sob minha orientação) e de uma técnica do Dieese, Suzanna Sochaczewski. Para cobrir os custos da parte da pesquisa sob minha responsabilidade, consegui um auxílio da Fapesp. Convidei para trabalhar na pesquisa Iram Jácome Rodrigues que foi comigo para Belo Horizonte. Depois que as tabelas ficaram prontas, a direção da CUT recebeu uma cópia. Terminei a análise dos dados e esperei um pouco para que a CUT publicasse os resulta- dos. Eu tinha pressa porque a editora Paz e Terra se interessara em publicar um livro de minha autoria sobre resultados da pesquisa e não eu não poderia esperar muito. Do ponto de vista comercial, não seria bom que um livro sobre o III Concut saísse depois do IV. Minha análise acabou indo para as livrarias em 1990 com o título CUT: os militantes e a ideologia, publicação da Paz e Terra.

A parte sob responsabilidade da CUT foi publicada por ela mesma no ano seguinte, em forma de caderno, com o título Retrato da CUT: delegados do III Concut. Representação das categorias. Está assinado por mim, Maria Silvia, Suzana e Iram. Soube depois que alguns dirigentes da CUT se sentiram passados para trás ou algo assim. Mas não havia acordo para dar à CUT a prioridade na publicação. A única restrição, com a qual concordei, foi que a análise dos dados relativos às delegadas ficaria a cargo da Suzana. Foi o que aconteceu. Os dados sobre as mulheres apareceram no caderno publicado pela CUT. Já a análise das teses e das tendências atuantes no congresso foi incluída no meu livro e excluída do caderno da CUT. Na realidade, a análise das tendências políticas que disputavam arduamente a direção da CUT (eram muitas) poderia acirrar os conflitos internos. Do ponto de vista da divulgação dos dados, não acho que houve algum prejuízo para a CUT. Apesar de focalizarem o mesmo objeto, os dois textos são bem diferentes. O livro ficou mais acadêmico, já o Caderno traz as tabelas com um mínimo de comentário. Mas é possível também que do meu livro certos dados não tenham agradado à direção da CUT, como, por exemplo, os que mostram a baixa rotatividade na ocupação dos postos de direção. Disse "é possível” porque ninguém veio reclamar comigo.

Você foi aos congressos anteriores para fazer uma prévia?

Não. Essa chance nunca apareceu. Mas isso não era necessário para a realização da pesquisa. Gostaria de discutir essa pesquisa do III Concut com vocês porque pode ter algum interesse do ponto de vista da técnica de pesquisas em reuniões com um número muito grande de participantes. Nesses casos, há uma dificuldade que vem da impossibilida- 
de de extrair com antecedência uma amostra. Isso acontece quando se quer trabalhar com questionários, mas não se sabe com exatidão quantas pessoas estarão presentes ou, pior ainda, quando não se tem a lista de participantes para um sorteio prévio de entrevistados.

Além do problema da amostragem, no caso do III Concut, havia a dificuldade da entrega dos questionários aos delegados e do controle de sua devolução. Também teríamos que ter um grau elevado de confiança de que os questionários não seriam respondidos por algum "assessor", pelo líder de alguma das facções ou pela chefia da delegação. A disputa entre as facções era muito renhida. Esse e provavelmente outros Concuts reuniam, de um lado, delegados de nível de escolaridade elevado, que dominavam as discussões e, de outro, delegados de qualificação educacional muito baixa. Cerca de $15 \%$ eram analfabetos ou tinham apenas um ano de escolaridade.

Os congressos da CUT eram congressos de massa. No III Concut, eram mais de seis mil delegados, o que significava mais dificuldade para a aplicação dos questionários. Além disso, a baixa escolaridade dificultava o preenchimento dos questionários. Seria aconselhável usar uma amostra para diminuir significativamente o número de entrevistados. Mas essa técnica se revelou impossível de ser utilizada. Por isso, chegamos à conclusão de que a probabilidade de um viés seria menor se tentássemos atingir o universo todo. A aplicação de um questionário preenchido pelos participantes teria que ser feito de uma só vez. É claro que isso afetaria o tipo de questionário a ser elaborado. Para começar, não poderia ser de preenchimento demorado. Teria que ser um questionário fechado, no qual os delegados iriam assinalar com um $x$ uma das alternativas apresentadas. Não teriam que escrever nada do próprio punho. A ocasião que nos pareceu mais adequada para a entrega e o recolhimento dos questionários foi a do credenciamento dos delegados, antes da abertura do congresso. Enormes filas se formariam. Haveria tempo suficiente para distribuição, preenchimento e recolhimento dos questionários. Contávamos com um número suficiente de auxiliares, alguns fornecidos pela própria CUT.
Em meio à distribuição dos questionários aconteceu algo inesperado revelando que na preparação de pesquisas nem sempre se consegue pensar em tudo. Tínhamos comprado muitas caixas de canetas Bic. Junto com o questionário, e com uma explicação sobre a natureza da pesquisa, entregávamos uma caneta que deveria ser recolhida junto com o questionário preenchido. Mas não contávamos com a eventualidade de a maioria das canetas não serem devolvidas. Foi o que aconteceu. Logo não havia mais caneta para entregar junto com os questionários.

Não era um congresso de estudantes ou de professores ou de gente de classe média. A maioria dos delegados não carregava caneta ou lápis. Portanto, necessitavam das Bics para responder ao questionário. Comecei a temer que essa "pequena" falha prejudicasse toda a pesquisa. No sufoco, disse a um dos auxiliares: "Compre umas dez caixas de Bic o mais rápido possível”. O único problema é que era o feriado do sete de setembro. O comércio estava todo fechado. Foi uma agonia. Finalmente, alguém conseguiu arrumar várias caixas de Bic, creio que cedidas pela secretaria do congresso. No final, atingimos cerca de $70 \%$ dos delegados.

\section{E a pesquisa sobre a Força Sindical?}

Na pesquisa sobre a Força Sindical, mais exatamente sobre seu congresso de fundação, a metodologia foi diferente. $\mathrm{O}$ congresso foi realizado em São Paulo, em março de 1991, no Memorial da América Latina. Da pesquisa, resultou um livro em parceria com Adalberto Moreira Cardoso, Força sindical: uma análise sócio-política, publicado em 1993, também pela editora Paz e Terra. Tal como no caso do III Concut, a pesquisa focalizou as características socioprofissionais dos delegados. Mas foi possível incluir algumas perguntas de natureza política, como partido preferido, voto nas eleições presidenciais etc. No III Concut, tínhamos preferido deixar as perguntas políticas de lado.

Desta feita, para a realização da pesquisa, a iniciativa não partiu da direção sindical. Foi uma sugestão feita a mim por Adalberto. Decidimos fazer a pesquisa uma semana antes do início do congresso. O tempo era curto, mas conseguimos fazê-la. 


\section{Usaram o mesmo questionário?}

Não, tivemos que fazer outro, mas aproveitamos algumas perguntas "objetivas", classificatórias, feitas no questionário da pesquisa da CUT. Junto com Adalberto, em poucas horas, elaboramos o questionário. Tiramos umas dez cópias para o pré-teste. Mudamos algumas questôes, mas pouca coisa. A direção da Força Sindical encarregou-se da impressão. No sábado pela manhã, o congresso começou. A idéia, seguindo a experiência do III Concut, era trabalhar com todo o universo.

$\mathrm{O}$ número de delegados era muito menor. Oficialmente seriam cerca de 1.700. Mas logo tivemos uma desagradável surpresa: a idéia de repetir a metodologia usada na pesquisa da CUT revelouse impossível. Uma parte dos delegados de fora de São Paulo tinha chegado na véspera e se credenciara antes. Outra parte estava chegando no próprio sábado. $\mathrm{O}$ resultado é que não havia filas de delegados para podermos distribuir e recolher os questionários antes do credenciamento. Os participantes chegavam, se credenciavam muito rapidamente e se dirigiam para o salão aonde iria se realizar o congresso. Tínhamos que abordar os participantes antes do credenciamento e lhes entregar o questionário. Tivemos que adotar outra estratégia não muito honesta. Mas foi para o bem. Fiz uma placa para pendurar no pescoço onde estava escrito: "Força Sindical" junto com o emblema da nova central. No momento da chegada do delegado dizíamos mais ou menos o seguinte: "O companheiro vai se credenciar? Por favor, vá para aquela mesa, mas antes preencha esse questionário. É importante para a Força Sindical". Na verdade, provavelmente, era mais importante para mim e para o Adalberto... Não era dito explicitamente que o preenchimento do questionário era condição para a participação. Mas dava essa impressão. Nesse momento, apareceu um pequeno problema. Adalberto, por motivos políticos, se recusou a usar o emblema da Força Sindical que nos dava um ar de autoridade... [risos]. E acabou ficando sem usá-lo. Bom, além de cercar os participantes na entrada, usamos um altofalante com mensagens lembrando aos esquecidos que não deixassem de preencher os questionários $\mathrm{e}$ colocá-los depois num enorme cesto situado na en- trada. Também percorríamos a sala de tempos em tempos lembrando aos delegados que estavam com questionários para que não deixassem de preenchêlo e devolver.

Não creio que tenha sido uma grande pesquisa, mas houve alguns achados interessantes. Ficou patente que a Força era bem mais fraca do que a CUT, mas de algum modo era mais "operária". Explico. Na CUT, a presença de metalúrgicos era forte. Em número absoluto muito maior do que na Força. Proporcionalmente, porém, havia na CUT mais sindicalistas das categorias de não manuais e de classe média, especialmente professores, funcionários públicos e bancários. No III Concut, havia uma distribuição meio esdrúxula, explicável em razão do peso de delegados de classe média assalariada e de trabalhadores rurais: grande proporção de trabalhadores de baixa escolaridade, num pólo, e alta proporção de delegados com curso superior, no outro (mais ou menos $20 \%$ ). Além disso, os delegados da CUT eram mais politizados. A ideologia de esquerda, ausente na Força, desempenhava um papel importante como motivação para a militância.

A pesquisa sobre a Força Sindical foi uma das últimas pesquisas empíricas que realizei na área $\mathrm{da}$ sociologia do trabalho. Houve outras que não citei aqui e que fiz com a participação de Iram Jácome Rodrigues: uma, com os empregados da Ford, em São Bernardo, outra, com os bancários de São Paulo, outra com os metalúrgicos de Santos. Mas acabamos não publicando nenhuma delas. Ou melhor, publiquei uma pequena parte da pesquisa da Ford no livro Partidos e sindicatos, com o título "Trabalhadores de uma indústria automobilística: perfil social e participação sindical". Iram também usou dados dessas pesquisas para seu mestrado e doutorado.

Posteriormente, usando dados estatísticos e fontes secundárias, fiz ainda um livro sobre a situação do sindicalismo nos países desenvolvidos da Europa e da América do Norte. Mais exatamente, foi um estudo sobre a queda das taxas de sindicalização. Concentrei a pesquisa nos países do Primeiro Mundo porque, de algum modo, eram eles que deixavam antever mais nitidamente o que estava acontecendo com as organizaçóes sindicais. O resultado desse estudo está no livro Destino do sindicalismo, que publiquei pela Editora da Universidade de São 
Paulo (Edusp). A primeira edição saiu em 1999 e a segunda em 2000. Sem falsa modéstia, penso que, no Brasil, fui o primeiro - ou um dos primeiros para não ser muito pretensioso - a chamar a atenção para o declínio do sindicalismo nas economias globalizadas. Quando, em 1995, estive em Genebra na reunião da OIT, como representante do governo brasileiro, aproveitei a ocasião para recolher dados sobre a situação do sindicalismo no mundo. As estatísticas mostraram uma queda geral, mas desigual, das taxas de filiação sindical nos vários países. Os sindicatos de trabalhadores mais afetados eram aqueles onde a automação estava mais avançada. No setor público, no entanto, onde a sindicalização ganhara impulso a partir da década de 1960, o declínio era bem menor. As causas não estavam apenas nas novas tecnologias, mas também em mudanças econômicas, políticas e valorativas nos países ocidentais. Minha conclusão era de que não se tratava de uma crise temporária do sindicalismo, mas de um declínio de difícil reversão.

Nessa época, eu estava começando a migrar para a sociologia política, vindo de estudos sobre o sindicalismo. Tinha escrito um capítulo, "Sindicalismo e classe operária - (1930-1964)", para o volume X da História geral da civilização brasileira, dirigida por Boris Fausto e publicada em 1981 pela Difel/Difusão Editorial. Ao investigar o sindicalismo da década de 1960 e a atuação do Comando Geral dos Trabalhadores (o CGT), encontrei o Partido Comunista Brasileiro. Nessa altura, o $\mathrm{PCB}$, agora aliado ao antigo rival PTB, controlava a maior parte do sindicalismo brasileiro. Veio daí a idéia da redação de um trabalho sobre a liderança do Partido Comunista Brasileiro. Esse trabalho saiu como um capítulo da mesma publicação intitulado "O PCB: a Ideologia e os Militantes. 1930-1964".

Mas o interesse pelo PCB não surgiu apenas da pesquisa sobre os sindicatos. Mais ou menos por essa época apareceram vários estudos sobre o PCB: o do Astrojildo Pereira e os dos brasilianistas John Foster Dulles e Ronald Chilcote, para citar os principais. É curioso como há certos temas - e autores - que, por razóes não muito claras, entram na moda e depois desaparecem. $\mathrm{Na}$ ocasião, o estudo sobre o PCB e sobre os partidos comunistas no mundo era uma das modas. Eu segui a onda.
Meu interesse não foi a história do PCB nem sua atuação política, mas o exame da composição social de sua liderança.

O levantamento das origens sociais, das profissões e ocupações dos principais dirigentes comunistas mostrou um recrutamento policlassista, com predominância de certos segmentos das classes médias: intelligentsia (jornalistas e professores), profissionais liberais (advogados e médicos, na maioria), militares do Exército (tenentes, capitães, sargentos e cabos), estudantes universitários e funcionários públicos. Mas o PCB recrutou também trabalhadores qualificados (operários fabris, ferroviários, portuários). No entanto, nenhum trabalhador manual chegou ao Bureau Político, a instância mais elevada de poder no partido. O recrutamento entre os camponeses, teoricamente uma das classes aliadas ao proletariado, foi mínimo.

Como era de se esperar, proprietários de modo geral não foram atraídos para o PCB. Mas, no exame das fontes de recrutamento, sempre é preciso levar em conta os períodos partidários, pois essas fontes tendem a variar com o tempo. $\mathrm{Na}$ formação do PCB, na década de 1920, além dos intelectuais de famílias tradicionais (Astrogildo Pereira, Osvaldo Brandão, por exemplo), o recém-fundado PCB atraiu alguns trabalhadores de formação artesanal (alfaiates, gráficos), talvez em razão das origens anarquistas do partido. $\mathrm{O}$ recrutamento de militares cresceu na década de 1930 com a adesão de Prestes ao comunismo e a formação da Aliança Nacional Libertadora. Depois de 1945, diminuiu bastante o recrutamento do PCB no meio militar.

Com o projeto de pesquisa sobre o PCB concorri por uma bolsa de pesquisa oferecida pela Fundação Guggenheim dos Estados Unidos. Era uma competição em escala latino-americana bastante acirrada, mas acabei sendo um dos contemplados.

\section{O Partido dos Trabalhadores}

Dessa preocupação de focalizar, além da atuação política e da ideologia, as características sociais dos atores, veio a idéia de um levantamento da composição das cúpulas do Partido dos Trabalhadores. Eu suspeitava que o espaço ocupado pelas 
classes trabalhadoras no novo partido não era tão grande e que a figura do Lula, a presença de sindicalistas e o nome do partido, tendiam a ocultar o espaço majoritário ocupado por segmentos das classes médias assalariadas de escolaridade elevada.

Resolvi pesquisar esse aspecto mais detidamente. $\mathrm{Na}$ realidade, a participação dos trabalhadores fabris, basicamente diretores de sindicatos, tinha sido dominante na formação do partido. Mas, aos poucos, os segmentos da classe média foram se tornando majoritários. Tomei para exame a Comissão Executiva Nacional eleita em 1987; os candidatos a deputados federais eleitos em 1986; os deputados petistas eleitos em 1986; e os candidatos à Assembléia Legislativa de São Paulo nas eleições de 1986. Em todas essas instancias predominavam professores, bancários e médicos. Mas havia também metalúrgicos, seguramente numa proporção muito maior do que em qualquer outro partido.

\section{A sociologia política}

A essa altura, eu tinha passado para o Departamento de Ciência Política, então sob a coordenação de Francisco Weffort. O cargo de titular estava vago desde a cassação de Fernando Henrique em 1969. Em 1968, ele venceu Paula Benguelman na disputa pela cátedra de Política. Contudo, poucos meses depois, junto com outros professores (Paula inclusive) foi aposentado compulsoriamente pelo AI-5. Depois da anistia de 1979, Fernando foi convidado para reassumir o cargo de titular mas não quis porque já estava mais voltado para a política. Nesse momento, eu e o Weffort éramos os mais titulados em condições de fazer concurso para o cargo de titular que tinha sido do Fernando. Achávamos que ninguém de fora viria disputar contra um de nós. Eu nunca pensara em concorrer contra Weffort, que era meu amigo desde os bancos da Faculdade, tinha sido da cadeira de Política desde sempre e tivera a generosidade de me acolher quando resolvi sair $\mathrm{da}$ Sociologia. Ele tinha sido assistente do professor Lourival Gomes Machado, antigo catedrático da Cadeira de Política. Eu vinha da Sociologia e tinha sido assistente do Florestan. Por isso, entre outros motivos, achava que Weffort deveria ter priorida- de para ocupar o cargo. Não havia mais razão para deixá-lo vazio. A inexistência de um professor titular enfraquecia o grupo. Tivemos uma conversa tête-à-tête. Nessa altura Weffort estava como secretário-geral do PT. Entendeu que seria melhor para o Departamento se eu concorresse porque eu estava mais ligado à universidade. Foi o que aconteceu. Fiz minha inscrição. Ninguém veio disputar comigo. Fui aprovado como seria de se esperar e passei a titular em 1981. Mais tarde, o Departamento de Ciência Política conseguiu a criação de outro cargo de titular. Weffort concorreu, também sem concorrentes, e foi aprovado.

Fiquei no Departamento até 1987, quando me aposentei da USP. A Unicamp, nessa altura, só tinha permissão da Capes para cursos de pós-graduação em nível de mestrado. Para nível de doutorado, necessitava de mais "massa crítica". O Departamento de Ciência Política da Unicamp teria que reforçar o corpo docente. Assim, fui contratado para dar aulas na pós-graduação da Unicamp. Vieram também outros professores: Juarez Brandão Lopes, Luciano Martins e Sebastião Velasco e Cruz. A Capes credenciou o doutoramento. Com o tempo, passei a dar aula também na graduação. Fiquei na Unicamp até 2003, quando me aposentei.

Voltando às pesquisas. $\mathrm{O}$ interesse pela composição e origem social dos que dirigem organizações políticas e sindicais voltou em mais três pesquisas sobre partidos e a classe política. A primeira foi sobre os constituintes de 1986. Está no livro Quem é quem na Constituinte, publicado em 1987 pela Oesp-Maltese. A segunda foi sobre os deputados federais eleitos em 1998. Está num livro Partidos, ideologia e composição social, publicado em 2002 pela Edusp. A terceira pesquisa foi sobre os deputados federais eleitos em 2002. Os resultados estão no livro Mudanças na classe política brasileira, publicado em 2006 pela Publifolha.

Começo falando sobre a pesquisa com os constituintes e sobre as razôes que me motivaram. Os resultados eleitorais, particularmente o crescimento fantástico do PMDB, o aparecimento do PT e do PSDB, o surgimento de novas chefias políticas, permitiam a hipótese de que o país não estava passando apenas por mudanças nas instituições do poder e no sistema partidário. Indicavam também 
que, junto com as transformações no sistema político - o retorno à democracia -, outras estariam ocorrendo de modo mais subterrâneo na estrutura social. Havia mudanças relacionadas com as próprias fontes de recrutamento político-partidário. A abertura democrática ampliara as oportunidades de ascensão de chefias políticas de origem popular.

A pesquisa sobre os constituintes permitiu uma primeira visão desses processos de mobilidade política. Foi minha primeira pesquisa grande na área da ciência política ou da sociologia política. Foi feita por meio de um questionário preenchido pelos constituintes e distribuído por jornalistas do Estadão e do Jornal da Tarde que faziam a cobertura dos trabalhos constituintes. Num total de 487 deputados, consegui um retorno de 451 questionários. A pesquisa mostrou o declínio no sistema político nacional das chamadas oligarquias tradicionais. Aumentara o espaço dos políticos vindos das classes médias e até mesmo das classes trabalhadoras. Contudo, as velhas famílias oligárquicas não tinham sido eliminadas do palco político. Elas se mantinham principalmente no Nordeste e Norte. Do controle do poder em nível regional, elas chegavam controlar partes significativas das estruturas de poder em âmbito federal. No entanto, no Sul e Sudeste, mudanças bastante profundas estavam se processando. Elas favoreciam a ascensão de novas lideranças de classe média e impunham novos esquemas de alianças partidárias.

Como indicação dessas alterações que ocasionavam o que chamei de "popularização" da classe política, dou apenas um dado que acho muito indicativo do movimento ascensional de políticos vindos da classe média e popular. No total de deputados que responderam ao questionário, cerca de um quinto disse que seus pais não tinham completado o primário, naquela época, de quatro anos de duração. Entre os deputados dos estados do Sul, a porcentagem era de aproximadamente $40 \%$. No Nordeste, era de $13 \%$, número indicativo de que o recrutamento político nessa região se fazia, em proporção bem maior do que no Sul e Sudeste, no interior das classes altas e da elite política local.

A pesquisa com os deputados federais eleitos em 1998 reforçou as indicações sobre a ampliação da participação de novas lideranças originárias das camadas populares e revelou significativas diferenças nas fontes de recrutamento partidário das bancadas. Era visível que os partidos brasileiros, embora recrutassem em vários segmentos da sociedade, não eram semelhantes do ponto de vista sociológico. Poder-se-ia até encontrar uma relação entre a ideologia e a linha política dos partidos e a composição socioprofissional de suas bancadas. Por exemplo, e de um modo simplista: os partidos considerados de direita, como o PFL e o PP, tinham significativamente mais empresários e pessoas de alta renda em suas bancadas, enquanto os partidos considerados de esquerda, o PT e o PCdoB, tinham suas bancadas compostas predominantemente por deputados que tinham sido professores, bancários, trabalhadores industriais e de outros estratos de classe média assalariada. Tinham também patrimônio bem mais baixo. Nos partidos considerados de centro, o PMDB e o PSDB, a composição era mais variada: havia menos empresários e deputados de renda elevada do que nos partidos de direita. Mas, de modo geral, eram formados de segmentos socioeconômicos mais elevados do que os deputados do PT e do PCdoB.

Estamos, assim, próximos da proposição marxista da relação entre classe social, ideologia e orientação política. Penso que ela permanece válida desde que não nos esqueçamos de levar em consideração outras variáveis, como os interesses de poder da própria classe política, os valores, os segmentos de classe específicos de onde vêm outras variáveis.

A pesquisa sobre os deputados eleitos em 2002 trouxe resultados que reforçaram a tese de que o celeiro social de recrutamento partidário tinha relação com as orientaçôes políticas e ideológicas. Em 1998, a eleição para a Câmara de Deputados fora influenciada pela vitória de Fernando Henrique. Em 2002, tinha havido a eleição do Lula e o crescimento do PT. Contudo, nas duas legislaturas, a relação entre origem social e partido permaneceu. Os perfis sociais dos partidos partidários se mantiveram apesar das alterações na dimensão das bancadas. Houve crescimento dos partidos de esquerda e declínio dos de direita. A conseqüência foi o aumento do número de deputados de origem popular. As bancadas sindicalista e evangélica cresceram. Embora as elites de origem oligárquica 
tenham conservado posições, a classe política brasileira tornou-se cada vez mais de classe média.

Queria que você falasse um pouco do Aziz Simão. Não há uma ponte entre os trabalhos de Azis Simão, de Albertino Rodrigues, e o Dieese? Quando você falou das discussóes existentes nas décadas de 1960 e 1970, houve um periodo em que pessoas próximas a você, como Fernando Henrique e Weffort, participaram de uma série de debates sobre a reestruturação de esquerda no Brasil etc. Depois, eles tomaram caminhos diferentes. Quero saber se você participou desses debates.

Vou começar pelo mais fácil [risos] e rápido: José Albertino. Embora o conhecesse e nos encontrássemos de vez em quando, tivemos pouca relação. Ele não lecionava na USP: estava no interior. Além disso, morreu muito cedo. Ele também foi diretor do Dieese. Tenho a impressão que ele estava mais próximo dos sindicatos do que do nosso meio acadêmico propriamente dito.

Mas você fez a apresentação de um livro dele...

Nós fizemos uma espécie de "troca", que hoje eu não faria. Ele tinha lançado um livro mais ou menos no mesmo momento em que eu estava lançando o meu. Ambos sobre trabalhadores e sindicatos. Não havia muitos "especialistas" na área. Eu imaginei que seríamos duas pessoas qualificadas, cujos comentários valorizariam o livro do outro. Se fosse apenas um de nós como comentarista, penso que tudo estaria bem. Mas não foi bom do jeito que ficou.

Por que você se arrependeu de ter feito essa troca?

Ficou parecendo uma ação entre amigos, o que, de fato, era. A nosso favor posso dizer que sempre, ou quase sempre, a apresentação de uma obra, como prefácio ou na contracapa, é um pouco uma ação entre amigos. As "orelhas" são sempre favoráveis ao autor. Servem para valorizar o livro e não para diminuí-lo. Se eu pedisse a Florestan ou a Fernando Henrique, tudo pareceria correto e normal, embora fôssemos do mesmo círculo de relacionamento.
Falando agora sobre Aziz Simão. Ele era de uma geração acima da minha. Tínhamos excelente relação. Ele era uma pessoa extraordinária. Ficou cego quando adulto. Não é preciso dizer que a falta de visão é uma limitação terrível. Por isso, Azis não escreveu muito. Mas se mantinha muito informado. Sua mulher e outras pessoas liam para ele. Uma vez dei a ele, em fita cassete, todo o meu capítulo sobre o PCB gravado por mim mesmo. Devemos a ele uma das primeiras pesquisas sobre sindicalismo, "O voto operário em São Paulo" de 1955 e, depois, o livro O Sindicato e o Estado, de 1966. São trabalhos anteriores aos outros, aos quais fiz referência, inclusive os meus. Azis tinha tido militância socialista. Creio que esse fato teve influência na escolha de seu objeto. Eu situaria Azis entre os pioneiros da sociologia do trabalho no Brasil.

E Weffort? Ele foi candidato a deputado federal, mas não se elegeu, não é?

Sim. Apesar de secretário-geral do partido, não se elegeu. Uma explicação que correu é que teria havido uma manobra do José Dirceu estimulando a candidatura de Florestan para dificultar a eleição de Weffort ao concorrer no mesmo espaço do eleitorado. Não tenho informaçôes a respeito. O que torna um pouco plausível essa história, mas não comprova sua veracidade, é que Florestan se inscreveu no partido no último dia em que se encerrava o prazo de inscrição para poder se candidatar para a Câmara. E conseguiu se eleger apesar disso. Ele tinha um prestígio difuso como intelectual opositor da ditadura. Creio que teve também o apoio de alguns dos movimentos negros.

\section{Florestan Fernandes}

Por que você acha que Florestan foi para o PT?

Não sei dizer. Acho que ele não participou da formação do partido. Se participou não teve papel importante. Mas devia ter simpatias pelo PT. Quando jovem, ele militou por cerca de quatro anos num pequeno grupo trotskista de São Paulo. Foi na épo- 
ca do Estado Novo. Essa informação está num capitulo de seu livro A sociologia no Brasil. De todo jeito, não teve papel importante no trotskismo.

Contudo, mesmo quando se ocupava mais da vida universitária e de sua carreira, continuava a ter uma "visão esquerdista" do mundo. Tinha certa dificuldade de lidar com poderosos, especialmente se fossem das classes ricas. Florestan, como sabemos, veio muito de baixo. Fez um esforço danado para ascender. A mãe era uma portuguesa, ex-lavadeira. Curiosamente, na descrição que faz de sua carreira, Florestan não faz referência ao pai. Morou com a mãe em cortiço e quartos de aluguel. Teve que trabalhar desde cedo. Foi engraxate, trabalhou em bares e restaurantes e depois como entregador de amostras de uma empresa farmacêutica. Antes tinha tido que abandonar a escola elementar no terceiro ano. Aos 17 anos voltou a estudar. Fez madureza e trabalhava enquanto estudava. Não veio, como outros professores da Faculdade de Filosofia, Ciências e Letras, de uma família paulista de quatrocentões de classe média ou alta, como Fernando de Azevedo, Antônio Candido de Mello e Souza, Maria Izaura de Queiroz, Lourival Gomes Machado, Ruy Coelho de Andrade Galvão, Sérgio Buarque de Hollanda, Maria Sylvia de Carvalho Franco... Mas é preciso dizer que, nesse aspecto, na minha época, a Faculdade de Filosofia já era bastante aberta e refletia, de algum modo, a composição étnica da sociedade paulista. No corpo docente havia muitos professores de famílias de imigrantes estrangeiros, na maioria de origem judia, italiana ou sírio-libanesa, como Paula Benguelman, Octávio Ianni, Azis Simão. O próprio Florestan, embora com muito esforço, chegara a fazer parte da elite acadêmica paulista. Penso que isso era uma indicação de que a sociedade paulista permitia alguma mobilidade social, mobilidade que Florestan subestimava.

O professor era pessoalmente corajoso. Em setembro de 1964, depois do golpe militar, fora convocado para depor num inquérito policial-militar (um IPM, como dizia) que tinha sido instalado na USP para "investigar atos de subversão e corrupção". A história tem a sua graça e vale a pena ser contada com um pouco de detalhe.

Alguns professores, tidos como de esquerda, tinham sido intimados a depor num IPM condu- zido por um coronel do Exército. Para tanto, uma pequena sala havia sido reservada pela direção da Faculdade. O primeiro a ser chamado para depor não tenho certeza - foi o professor Cruz Costa, catedrático do Departamento de Filosofia. Consta que, lá pelas tantas, o coronel lhe perguntou se ele sabia cantar o Hino Nacional. Cruz Costa, que tinha muito espírito, respondeu: "Sozinho não sei, mas se o senhor cantar, eu acompanho". Não me lembro de como terminou a história, mas nenhuma medida foi tomada contra Cruz Costa que, aliás, não tinha nada de esquerdista.

No caso do Florestan foi diferente. Ele não se recusou a depor. Mas, ao entrar na sala do IPM, onde o coronel o esperava, tirou do bolso uma carta onde dizia que tinha recebido a convocação como uma injúria, mas que tivera que aceitar. Entregou ao coronel. A carta era educada, mas o coronel não gostou e respondeu: "Considere-se preso" [risos]. Florestan obteve permissão para a ir até seu escritório antes de acompanhar o coronel ao quartel. Tudo muito cavalheiresco. Eu estava na faculdade, esperando ansioso para saber o resultado do depoimento do chefe. Quando Florestan saiu da sala do IPM, me viu e disse: "Leôncio, estou preso. Entregue essa carta aos estudantes".

Em três tempos a carta estava mimeografada e divulgada nos jornais, que deram em manchete: "Florestan preso". O impacto na opiniāo pública foi enorme. Tinha sido conduzido a um quartel em São Paulo mesmo. Quando ele estava detido, fui visitá-lo com Procópio Camargo (que mais tarde foi presidente do Cebrap). Procópio teve a idéia de levarmos uma caixa de bombons de presente. Achei engraçada a iniciativa, mas concordei. E Florestan recebeu na prisão um presente que talvez não fosse muito habitual.

Depois de três dias, ele foi solto. Fui buscá-lo de automóvel no quartel. "O senhor quer ir para casa?" perguntei. "Não, eu quero ir para a Faculdade". Ele tinha um certo senso de criação do fato político. Quando chegamos no prédio da faculdade, na rua Maria Antônia, aconteceu algo surpreendente e emocionante. Nada tinha sido preparado para recebê-lo. Os alunos nem sabiam que o professor seria solto. Ele chegou de surpresa. Ao entrarmos pela porta principal, o bedel e outras pessoas que estavam no saguão de entrada, reconheceram-no. 
Começaram espontaneamente a bater palmas. O barulho chamou atenção de outros funcionários e alunos que saíram das salas de aula para ver o que se passava. Viram Florestan e começaram também a aplaudir, sem dizer nada. Até hoje me emociono quando me lembro da cena. As nossas salas de trabalho eram no segundo andar. Florestan foi subindo as escadas. Mais gente aparecia para aplaudi-lo. Ele ia agradecendo, meio sem jeito. No final, havia uma multidão batendo palmas. Não houve discursos. Foi tudo muito autêntico e inesperado. Por isso, foi muito emocionante. Essa cena ocorreu de dia. Creio que no período da manhã. Ante o sucesso, resolvemos repetir o evento à noite, explorando-o politicamente. A mídia foi convocada com antecedência. Florestan repetiu a entrada na faculdade, com muita gente à espera no saguão de entrada. $\mathrm{O}$ diretório estudantil havia sido informado. A TV e a imprensa estavam presentes. Mas desta feita a cena não foi tão impactante. De todo jeito, FF, como o chamávamos às vezes, conseguiu acabar com o IPM na faculdade. Depois disso, não se falou mais em IPM. Ele se tornou também bastante conhecido, o que provavelmente ajudou, muitos anos depois, sua eleição para a Câmara dos Deputados.

Alguém perguntou por que acho que Florestan foi para o PT. Não é fácil captar as motivaçôes das pessoas, especialmente quando fazem política, atividade muito mistificada, manifestamente sempre efetuada em benefício de outrem, nunca do político. No caso de Florestan, acho que, efetivamente, ele tinha uma visão do mundo radical. Eleito, não se destacou na Câmara nem no PT, talvez por ser muito individualista e não saber "fazer política". A atuação na Câmara, e em outros órgãos com muitas pessoas que são formalmente iguais, requer capacidade de barganha, de conchavo, de adaptação a um grupo. Minha impressão é que Florestan não tinha essa capacidade.

Como é que você vê a relação que os intelectuais constroem com os trabalhadores, com os sindicatos? Você acha que a sua relação com os sindicatos mudou ao longo do tempo? Você se pensava como um intelectual que iria ajudar o sindicato, ou como um intelectual que simplesmente iria lá, faria uma análise e apresentaria para o grande público?
São várias perguntas, algumas delas difíceis de responder. Vou tentar dizer alguma coisa começando por mim mesmo. Em todas pesquisas que realizei como sociólogo, minha preocupação era fazer um bom trabalho acadêmico. Queria escutar mais do que falar, entender mais do que mudar, justamente o contrário do que faria um bom militante, intelectual de esquerda ou um político.

$\mathrm{E}$, neste ponto, penso que convém não confundir o sociólogo com o intelectual. O risco aqui é cair numa discussão sobre a definição de intelectual, discussão que não terminaria nunca e nos levaria a tentar classificar os tipos de intelectual. Mas, qualquer que seja a definição, geralmente o intelectual é alguém que fala para a sociedade e divulga uma verdade que contém uma crítica, mais ácida ou mais suave, à ordem existente. Por isso, o contacto dos chamados "intelectuais críticos" com as classes trabalhadoras sempre acaba tendo um componente político. $\mathrm{O}$ intelectual pretende ser a figura dominante dessa relação, passar uma mensagem que se legitima pelo saber que supostamente teria. No caso da visão leninista, a posição dominante do intelectual é explícita. Sem o intelectual socialista, que dominaria a teoria marxista, a classe operária "por si só”, como dizia Lênin no Que fazer, não vai além do economicismo.

Nas situações em que a classe operária está desorganizada sindicalmente, é muito pobre e humilde, os intelectuais de esquerda podem efetivamente ter alguma influência doutrinária e política sobre os trabalhadores e os pobres. No entanto, quando há sindicatos fortes com lideranças vindas do próprio meio, a influência dos intelectuais de esquerda, normalmente efetivada por meio de um partido, tende a se reduzir ou mesmo a desaparecer. As lideranças sindicais não gostam desses intrusos que se metem na seara alheia e pretendem ganhar a sua clientela. Os sindicalistas tendem a ser reformistas e moderados; os intelectuais tendem a ser críticos do status quo e freqüentemente das chefias sindicais moderadas ou conformistas.

Assim, vejo uma diferença entre o intelectual e o sociólogo do trabalho. Ao contrário do intelectual, o sociólogo é, ou deveria ser, um profissional que pretende analisar um objeto, um sindicato, um grupo de trabalhadores, geralmente. Não deveria querer doutrinar os trabalhadores. Portanto, em princípio, teria menos atritos com as chefias dos 
sindicatos. Mas, mesmo se limitando ao seu trabalho de pesquisa, pode ter atritos com lideranças sindicais. Os sindicatos são instituições burocráticas com interesses próprios. Quase sempre estão divididos em facções. O sociólogo do trabalho, para fazer uma pesquisa com alguma objetividade, pode ter que revelar aspectos que as chefias sindicais não gostariam de ver divulgadas. Assim, mesmo não sendo um militante revolucionário que pretenda influenciar os associados, um pesquisador "neutro" pode se ver também em situações delicadas que o levariam a atritar com as cúpulas sindicais.

Mas de que maneira você, como pesquisador, como intelectual, se enquadra nessa análise ampla que acabou de fazer?

É uma boa pergunta... Podemos passar para outra? [risos]. Eu me via simplesmente fazendo um trabalho acadêmico sobre um assunto que me interessava. Obviamente, tinha muita simpatia com meu objeto. Sem essa simpatia dificilmente se pode fazer um bom trabalho. Mas não tinha nenhuma pretensão de influenciar os trabalhadores.

Pensando um pouco nos contatos, nas interlocuçôes nacionais e internacionais... Você falou de Touraine naquele período, mas na medida em que você foi consolidando a carreira e amadurecendo que contatos nacionais foram importantes? Eventualmente só se deram num âmbito de rede, como a da Anpocs por exemplo, $e$ também no âmbito internacional?

Em termos de estágio ou trabalho no exterior, em comparação com alguns colegas de nível profissional mais ou menos igual ao meu, minha experiência internacional não foi grande. Passei, em 1969-1970, um ano escolar como professor-visitante na Universidade Católica de Louvain, na Bélgica. Naturalmente, estive muitas vezes fora do Brasil em congressos e reuniōes e estágios de curta duração. Fiz palestras em outros países e estive por três ou quatro vezes como diretor-associado na École Practique des Hautes Études, a convite de Touraine e Bourdieu. Mas foram curtas temporadas de um mês. Ao contrário de vários colegas que passaram anos de sua vida acadêmica estudando ou lecionando em uni- versidades estrangeiras, sempre tive dificuldade para morar no exterior. Não gosto de me sentir estrangeiro. Gosto de viver no Brasil. Não consigo produzir intelectualmente ou pesquisar fora daqui.

Os trabalhos do Touraine sobre o sindicalismo e a classe operária me influenciaram. $\mathrm{Na}$ tese de doutorado, utilizei alguns de seus conceitos. Mas não posso me considerar seu discípulo ou seguidor. Não consegui acompanhar suas consideraçôes sobre a "sociologia da ação". Às vezes, não entendia ou não achava corretas certas passagens. Mas tinha boas relações com ele e lia seus escritos. Eu o achava muito inventivo e estimulante. Aqui, da América Latina, gosto dos trabalhos do argentino Torcuato Di Tella, de quem sou amigo há muito anos. Torcuato, que é realmente um intelectual cosmopolita, tem muitos estudos sobre sindicalismo e classes trabalhadoras. Gosto do tipo de análise que ele faz. Não é exatamente political science, mas sociologia política focalizando, geralmente de um modo "macro", os movimentos sociais e políticos, os partidos e o sindicalismo da América Latina. Mas de modo geral, tenho uma visão eclética das ciências sociais. Não me pretendo discípulo de ninguém ou seguidor de alguma escola, o que me dá mais liberdade para me apoiar e buscar dados em várias fontes.

Bem, tentei fazer um breve relato de minha carreira acadêmica e transmitir alguma informação sobre o aparecimento da sociologia do trabalho em São Paulo. Também procurei passar, de modo bem sintético, um ou outro dado mais concreto vindos das pesquisas que efetuei. Mas tenho consciência de que foi tudo um pouco superficial. Agradeço a José Ricardo e a todos vocês a paciência de me escutarem. Para mim, foi realmente um encontro muito estimulante.

\section{Notas}

1 Além dos professores do curso "Sociologia do Trabalho no Brasil", José Ricardo Ramalho e Marco Aurélio Santana, participaram também da entrevista os professores Elina Pessanha (PPGSA-UFRJ) e José Sérgio Leite Lopes (PPGAS-UFRJ), e os alunos do Programa de Pós-Graduação em Sociologia e Antropologia do Instituto de Filosofia e Ciências Sociais da UFRJ. 


\section{SOCIOLOGIA DO TRABALHO NO BRASIL: ENTREVISTA COM LEÔNCIO MARTINS RODRIGUES} José Ricardo Ramalho e Iram Jácome
Rodrigues

Palavras-chave: Sociologia do trabalho; Sociologia política; Intelectuais brasileiros; Partidos e sindicatos no Brasil.

Leôncio Martins Rodrigues concedeu esta entrevista no dia 10 de setembro de 2007, durante sessão do curso "Sociologia do Trabalho no Brasil" ministrado no Instituto de Filosofia e Ciências Sociais da Universidade Federal do Rio de Janeiro. O relato aborda aspectos de sua vida pessoal e familiar, de sua formação política e de sua trajetória como estudante, professor e pesquisador das ciências sociais, especialmente com relação aos temas do trabalho, do sindicato e dos partidos políticos. Descreve sua forte ligação com a USP e com o grupo de professores e depois colegas que estiveram sob a orientação acadêmica de Florestan Fernandes. Relembra, ainda, com detalhes, os procedimentos e as dificuldades das várias investigações que realizou em fábricas e congressos sindicais, que posteriormente se tornaram livros e estimularam debates.

\section{SOCIOLOGY OF LABOR IN BRAZIL: AN INTERVIEW WITH LEÔNCIO MARTINS RODRIGUES}

\section{José Ricardo Ramalho e Iram Jácome Rodrigues}

Keywords: Sociology of labor; Political sociology; Brazilian intellectuals; Parties and unions in Brazil.

Leôncio Martins Rodrigues gave this interview on September 10, 2007, during a session in the course "Sociology Labor in Brazil," held at the Philosophy and Social Sciences Institute of Rio de Janeiro Federal University. The report approaches aspects of his personal and family life, his political formation, as well as his career as student, professor, and researcher in social sciences, especially relating to themes regarding work, unions, and political parties. It describes his strong connection to both USP and a group of professors, later becoming colleagues who had been under the academic orientation of Florestan Fernandes. It also brings to memory, in detail, procedures and difficulties of various investigations he carried out in factories and union congresses, the later became books and provoked debates.

\section{SOCIOLOGIE DU TRAVAIL AU BRÉSIL: INTERVIEW AVEC LEÔNCIO MARTINS RODRIGUES}

\author{
José Ricardo Ramalho et Iram Jácome \\ Rodrigues
}

Mots-clés: Sociologie du travail; Sociologie politique; Intellectuels brésiliens; Partis et syndicats au Brésil.

Leôncio Martins Rodrigues a accordé cet interview le 10 septembre 2007, lors d'une session du cours "Sociologie du Travail au Brésil” proféré à l'Institut de Philosophie et de Sciences Sociales de l'Université Fédérale de Rio de Janeiro. Le récit aborde des aspects de sa vie personnelle et familiale, de sa formation politique et de sa trajectoire en tant qu'étudiant, professeur et chercheur en sciences sociales, particulièrement par rapport aux thèmes du travail, du syndicat et des partis politiques. Il décrit sa forte liaison avec l'Université de São Paulo et un groupe de professeurs - par la suite, collègues - qui ont travaillé sous la direction académique de Florestan Fernandes. Il rappele également, avec détails, les procédures et les difficultées des plusieurs recherches qu'il a entrepris dans les usines et les congrès syndicaux qui, postérieurement, sont devenus des livres et ont stimulé les débats. 